\title{
9. 輸入感染症
}

查林大学医学部寄生蜉过守守康

Key words：熱带病，マラリア，血清竞断，稀用薬

\section{はじめに}

近年感染症ことに寄生虫性疾患が少なくなった といわれ，軽視される傾向がないでもないが，最 近の海外旅行やグルメプーム，さらにはペットを 飼与家庭の増加に加壳て各種検查法の進歩などに よりこれまでわが国では余りみられなかった疾患 の症例が多くなっている。輸入感染症の増加に 伴って起こる問題としては，医師など医療従事者 の中にはこれらの疾患を実際に経験したことが無 い世代が増えているため，かなりの症例が見逃さ れたり放置されていることである。この場合放置 されていてす他に伝播せず重症化しないケースは 比較的問題は少ないが，アメーバ症のように他に 感染が拡大するものや，マラリア，トリパノソー マ症のごとく致死的経過をとる場合は極めて重大 である，そこで最近私どもが遭遇する輸入感染症 について述べてみたい。

\section{1. わが国の輸入感染症の現状}

昨年の 1 年間に厚生省に届出られた法定あるい は届出伝染病は表 1 に示すごとくであるが，その 中外国旅行で䍜患した症例はコレラ45例，細菌性 赤浰 546 例，アメーバ性赤浰 30 例, 腸チフス30例, パラチフス19例，マラリフ46例の計716例であっ た。これら輸入感染症のらち細菌性, ウイルス性 疾患は検疫所や各医療機関で行政的にも管理・監
表 1，厚生省比届出のあった伝染病症例数

\begin{tabular}{|c|c|c|c|}
\hline \multicolumn{4}{|c|}{ （1992年 1～-12月） } \\
\hline & 耘 & 国內感染 & 国外感染 \\
\hline$コ レ ラ$ & 51 & 4 & 45 \\
\hline 細菌性赤莉 & 943 & 316 & 546 \\
\hline アメーバ性赤浰 & 133 & 72 & 30 \\
\hline 腸チフス & 71 & 28 & 30 \\
\hline パラチフス & 32 & 9 & 19 \\
\hline マシリア & 47 & 1 & 46 \\
\hline 症例絰数 & 1277 & 430 & 716 \\
\hline
\end{tabular}

視されているが，寄生虫性疾患はその臨床経過が 慢性的なこともあって臨末家が看過する傾向がな いでもない、しかし現在な打東南アジアやアフリ カなどの開発途上国では寄生虫性疾患の感染率が $90 \%$ 以上を示すところが多く，持続性下阙，負血， 好酸球增加など奇生虫症が疑われる症例に遭遇し た場合には問診で海外旅行の有無を問い質すこと が必要である。マラッフおよびアメーバ性赤峲の 実数は表 1 に記された数よりは多く，例学ば1990 年, 91年のマラリア患者は厚生省への届出数がそ れぞれ55例，58例であるが，輸入寄生虫症に関す る研究班が全国の医療機関に対して行ったアン ケート調查の結果はそれぞれ110例，89例であり， 臨床各科で扱っている実際の症例数はこの数倍に 及ぶものと推定される。な持熱带熱マラリアによ る死亡例数は過去 25 年間に 74 例が集計され，年平 均 3 例が死亡していることも注目すべきである。 


\section{2. 最近の輸入寄生虫症}

輸入寄生虫症は海外旅行者の感染例の他に寄生 虫に感染また活染されている輸入食品や輸入動 物と共にわが国に持ち込末れ，国内で感染する(例 壳ば輸入ドジョウの生食により感染する剛棘顎口 虫症）症例も多くみられるようになっている，現 在わが国の検便による笴生虫卵の陽性率は全国平 均が $0.15 \%$ 程度であるが，表 2 に示すごとく 1980 年から87年までの 8 年間の輸入寄生虫症例が 383 例，1988年から90年末での 3 年間が397例と，国際 交流が盛んになるに伴い増加の傾向がみられてい る。この症例数は臨床診療科に依頼したものでは なく，全国の寄生虫学関係の教室扰よび研究所か らの限られた報告であるので実際にはこの数倍の 症例が存在するものと思われる。この中で特に多 かったのはマラリアで，1980年から90年の11年間 で563例もあり，先に述べたごとく死亡例も多い。 1990年のマラリア患者の推定感染地域之原虫種を 緾めたのが表 3 であるが，死亡例の出ている熱帯

表 2. 厚生省研究班が把握した輸入熱带性奇生虫病症例数

(高田ら, 1991)

\begin{tabular}{|c|c|c|}
\hline 疾 患 名 & $1980 \sim 1987$ & $1988 \sim 1990$ \\
\hline (0) $>\quad$ ज & $268(57)$ & 295 \\
\hline (Oトvハ, y- - 症 & 1 & 1 \\
\hline (9)皮膚リーシュマニア症 & 1 & 11 \\
\hline ○カラ・アザール & 1 & 4 \\
\hline Yィーバ性赤峲 & 2 & 19 \\
\hline ランブル鞭毛虫庭 & $21(1)$ & 11 \\
\hline (O)マンンン住血吸虫症 & 1 & 0 \\
\hline ○ビルハルッ住血吸虫症 & 3 & 0 \\
\hline 日本住血吸虫痘 & 3 & 1 \\
\hline 肝西虫症 & $32(16)$ & 3 \\
\hline 楩＜wide>虫 & $30(18)$ & 5 \\
\hline 旋 毛 虫 症 & 3 & 0 \\
\hline 無 鈎 条 虫 症 & $10(4)$ & 21 \\
\hline 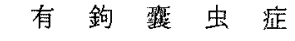 & $11(11)$ & 18 \\
\hline 专の他の条虫症 & 7 & 8 \\
\hline 計 & $383(96)$ & 397 \\
\hline
\end{tabular}

○日本に常在しない寄生虫症

( ) 外国人症例数
表 3.1990年のマラリア推定感染地域と原虫種

\begin{tabular}{c|c|c|c|c|c|c}
\multicolumn{1}{c}{} & \multicolumn{4}{c}{ (大友ら, 1992) } \\
\hline 感染地域 & 熱帯熱 & 三日熱 & 卵型 & 混合 & 不明 & 計 \\
\hline 東南アジ & 9 & 39 & 0 & 3 & 0 & 51 \\
西太平洋 & 2 & 8 & 0 & 0 & 0 & 10 \\
アフリカ & 28 & 7 & 3 & 2 & 1 & 41 \\
中南 米 & 0 & 6 & 0 & 0 & 0 & 6 \\
不 明 & 0 & 1 & 0 & 0 & 1 & 2 \\
\hline 計 & $39 *$ & 61 & 3 & 5 & 2 & 110 \\
\hline
\end{tabular}

熱マラリアはアフリカ旅行者に多く, 三日熱マラ リアは東南アジア地域に多い。な和この年には四 日熱マラリアと確定診断された症例は認められな かったが，私が関係している中央フフリカでは一 般住民の䄪 $50 \%$ から熱帯熱原虫が検出されると同 時に，四日熱原虫も約 $25 \%$ の人から証明されてい るので，決して無視することは出来ない，次に多 いのは原虫症ではランブル鞭毛虫症の32例と赤病 アメーバ症の21例であるが，ランブル鞭毛虫症は 早くから旅行者下痢症の主な原因とされて和り， 赤痢アメージ症は輸入症例としてと同時に最近は STD (性行為感染症)としても注目されている. その他原虫症で問題となるのは本来わが国には常 在しない各種りーシュマニア症で, 特に致死的な カラ・アザールの増加が心配され，1990年には 2 例の死亡例が報告されて括り，何れす中国東北部 で感染したと記録されている，蠕虫症ではマンン ンおよびビルハルッ住血吸虫症の 4 例はすべてア フリカで霍患したもので，日本住血吸虫症の 4 例 は中国で感染した症例である。な括マンソン住血 吸虫は今回は旅行者が少なかった故か症例報告が 無かったが，中南米にも存在することを留意する ベきである，肝吸虫症の35例は韓国，中国，香港 などで淡水魚を生食した人が多く，鞭虫症は閉発 途上国ではかなり蔓延しているので多いのは当然 である，旋毛虫症の3例はタイとインドネシアで 罹患した症例である。この表には記載していない が，輸入ドジョウの“拈どりぐい”による剛棘顎 口虫症は1980年頃より多発し，これまでに50例以 
上が報告されている，風棘顎口虫は本来日本には 存在せず，東南アジアの豚の胃壁に寄生するもの であるが，その幼蛙が輸入ドジョウを介して人に 感染し皮膚幼虫移行症を起こすものである。条虫 関係では無銁条虫症が31例，有鈎郦虫症が29例之 特に多いが，中でも脳有鈎喛虫症の場合は症状む 重篤で死に至ることもまれではない，患者は主に 韓国，中国籍の人に多くみられるが，日本人から も証明されているので，将来注意すべ疾患の一 つである、な技表中に@印で示したわが国に常在 しない寄生虫症の数は，確定診断された症例のみ であって，誤診されたり，診断のつかないまま放 置されているものもかなり存在するものと推定さ れる。

\section{3. 医療機関から依頼の蠕虫症血清反応成 績}

寄生虫症の確定診断は検便あるい性検などに 上り形態学的に虫畉または虫体を証明することで あるが，通常の検便のみでは診断し得ない幼虫移 行症や臓器寄生の螦虫性疾患も多い。昨年 1 年間 に私どものところで行った寄生虫症に対する血清 検査の依頼は706検体であるが, その中経過観察で 重複している検体扔よびニューモシスチス・カリ 二肺炎など原虫症を対象とした症例を除いた蠕虫 検查依頼症例数は表 4 に示すごとく490例で, その 中約 $29 \%$ \% 144例が何らかの蠕虫抗原で陽性を呈 てている.このらち卯を付したものが輸入感染症 例で，顎口虫抗体陽性の 2 名はドジョウの“扣ど りぐい”の後，皮䖉に爬行性腫脹を認めて扣り， マンソン住血吸虫抗体陽性の 3 名はグループでア フリカのマラウイを訪れ，水浴をしたとのことで ある、この中の 2 名の尿からピルハルッ住血吸虫 の虫卵が検出された。エキノコッカス抗体陽性の 症例はアフガニスタンを旅行した人である.

ここで寄生蠕虫症におけける血清診断について若 干述べてみると, 蜔虫, 鉤虫, 肝吸虫, 横川吸虫, 無鈎条虫，広節裂頭条虫など消化管腔奇生の蠕虫 感染症では抗体価が低く，通常血清反応の意味は
表 4. 寄生蠕虫症血清反応成績 （梠林大笴生虫，1992年 1～12月）

\begin{tabular}{|c|c|c|}
\hline \multicolumn{2}{|c|}{ 線虫類 } & （例数） \\
\hline \multicolumn{2}{|c|}{ アニサキス } & 28 \\
\hline \multicolumn{2}{|c|}{ 犬蝈虫 } & 66 \\
\hline \multicolumn{2}{|c|}{ 鈎虫 } & 2 \\
\hline \multicolumn{2}{|c|}{ \#䫁口虫 } & 2 \\
\hline \multicolumn{2}{|c|}{ 広東住血線虫 } & 7 \\
\hline \multicolumn{2}{|c|}{ 犬系状虫 } & 1 \\
\hline \multicolumn{3}{|c|}{ 昅虫類 } \\
\hline \multicolumn{2}{|c|}{ 宮崎肺吸虫 } & 7 \\
\hline \multicolumn{2}{|c|}{ 盰蛭 } & 2 \\
\hline \multicolumn{2}{|c|}{ \#マンンン住血吸虫 } & 3 \\
\hline \multicolumn{3}{|c|}{ 条虫類 } \\
\hline \multicolumn{2}{|c|}{ マンンン弧虫 } & 3 \\
\hline \multicolumn{2}{|c|}{ \#エキノコッカス } & 1 \\
\hline \multicolumn{3}{|c|}{ その他 } \\
\hline \multicolumn{3}{|c|}{$\begin{array}{l}\text { 奇生蠕虫症以外の免疫翼常疾患之 } \\
\text { 思われるもの }\end{array}$} \\
\hline \multicolumn{2}{|r|}{ （漬瘍性大腸炎，膠原病など） } & 22 \\
\hline 陽 & 性 & $144(29.4 \%)$ \\
\hline \multirow[t]{2}{*}{ 陰 } & 性 & 346 \\
\hline & 計 & 490 \\
\hline
\end{tabular}

殆ど認められないが，これら消化管腔寄生蠕虫症 は検便により容易に虫卵が証明し得る疾患であ る。一方人を非固有宿主とし，幼虫移行症を来一 アニサキス, 犬・猫蜔虫, 買口虫, 有鉤壁虫, 工 キノコッカス，マンソン孤虫中組織内寄生虫であ る系状虫, 日本住血吸虫, 肺吸虫の感染症では形 態学的診断が困難であるが，血清反心は何れも $85 \%$ 以上の陽性一致率を示し，血清学的診断法が 大きな意義を持っている。またこれらの組織内寄 生虫の場合は血清反応とともにェコーやCTなど の画像診断が役立っている，従って奇生蠕蛙症 疑う症例に遭遇した場合にはその寄生虫に合った 検查法を選択することが重要である。

\section{4. 輸入寄生虫症の治療}

従来わが国に存在しなかった寄生虫の感染が証 明された場合に，実地臨木医の方々が々の治療法 


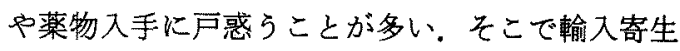
虫症に限らず寄生虫性疾患に対する治療薬につい て述べてみる。これまでは外国ではすでに販売さ れていてもわが国では入手困難であった薬物が多 かったが，輸入寄生虫病の增加に伴い，3年程前 より多くの駆虫薬がいわゆる稀用薬として厚生省 で認可され発売されるようになっている。

\section{1）抗原虫薬}

(1) =トロイミダゾール系としてメトロニダ ゾールとチニダゾールがあるが，何れも赤痢ア メーバ，ランブル鞭毛虫括よび胵トリコモナス感 染症に対する薬物で，メトロニダゾールには胠錠 あある。

（2）ピリメサミンとスルファドキシンの合剤は マラリア,トキソブラスマ症, ニューモシスチス・ カリ ( $(\mathrm{Pc})$ 肺炎に対する薬物として用いられる.

(3) アセチルスピラマイシンはトキップラスマ 症の治療薬として用いられる。

（4）イソチオン酸ペンタミシンはPc肺炎, トリ パノソーマ症执よびリーシュマニア症の治療注射 薬として用いられるが，腎拈よび肝障害，低血糖， 注射局所の激痛，壊死などの副作用が強いので注 意を要する。最近Pc肺炎に対しては本薬のネブラ イザー投与が行われ，副作用も無く良い成績が得 られている。李たHIV抗体陽性者に対して本薬の ネブライザー投与を毎月 1 回行うことにより Pc 肺炎の発症を抑制することも報告され，予防薬と しても広く用いられている。

（5）トリメトプリムとスルファメトキサゾール の合剂はPC肺炎, トキソプラスマ症括よびマラリ アの治療薬として用いられて牤り，特にPc肺炎に 対しては第一選択薬として使用され，末た治療量 の $1 / 4$ 量か $1 / 5$ 量を予防薬量として投与することが 行われているが，エイズに併発したPc肺炎の患者 では嘔吐や皮沴などの副作用がみられるので，先 のインチオン酸ペンタミシンンのネ゙ライザー療法 の方が望ましい。

(6) スルファモノメトキシンはトキソプラスマ 症の治療薬として用いられ, Pc肺资に対しても或 程度の効果が期待出来るが, サルファ薬の単独投
与よりも(2)怙よび(5)のピリメサミンかトリメト プリムとの併用療法の方がより效果が認められ る。

\section{2）抗蠕虫薬}

（1）パモ酸ピランテルが消化管奇生線虫症の広 域駆虫薬としてわが国では20年程前から発売され 広く知られている。本薬は蚼虫症, 鈎虫症, 蟯虫 症に対しては95〜100\%の効果が認められるが,東 洋毛様線虫症では70 80\%の奻果しか認められな い. 1 回の投与で完治しない場合には副作用も殆 ど認められないので反復投薬を行う。

（2）サイアベンダゾールは広域抗線虫薬で特に 冀線虫やフィリピン毛頭虫の感染症に有妙である ことが知られて拈り，フィリピン毛頭虫の感染に よる腸カピラリフ症の場合には 1 カ月間の継続投 与が必要である。本薬はまた犬・猫蜔虫定や旋毛 虫症の後期など幼線虫期に対してる効果があるこ とが知られている。

（3）メベンダゾールは鞭虫症を適応として許可 された薬物であるが，その他旋毛虫症，腸カピラ リア症, 蜔虫症などに対しても有効であり, 顎口 虫, 無鈞条虫, 裂頭条虫, 小形条虫, マンソン孤 虫などの感染の場合には或る程度の効果が期待出 来る。

(4) クェン酸ジェチルカルバマジンは抗フィラ リ丁薬すなわち抗系状虫薬として古くから知られ ているが，犬・猫蜔虫症や顎口虫症などの幼線虫 移行症に対しても効果があることが認められてい 当。

（5）プラジカソテルはわが国では肝吸虫症の治 療薬として諗可発売されているが，元来は抗住血 吸虫薬として開発，発売されたものでその他肺吸 虫, 肝蛭, 横川吸虫, 無銁条虫, 裂頭条虫, 小形 条虫, マンソン孤虫, 有鉤条虫, 有鈎䉴虫などの 感染症に対しても有効であることが知られてお り，広域抗吸虫・抗条虫薬として用いられている， な挌本薬はエキノコッカス症に対しては無効であ 万.

（6）ビチオノールは元来動物の肝蛭治療薬とし て開発されたものであるが，肺吸虫症に対しても 
有効であることが判り，わが国で人体用として製 造販売されるよらになった薬物である、肺吸虫症 と肝蛭症に対してはプラジカンテルよりる効果が 高いが，プラジカンテルは1〜2 日間の投与でよ いのに対し，本薬は隔日10回すなわち20日間が必 要であり，また時に悪心，湢吐などの副作用がみ られることがあるので現在はプラジカンテル無効 例に対して使用されることが多い。な打横川吸虫 に対しては隔日 5 回，条虫の成虫に対しては 1 日 の投与で良い。

（7）カマラは古くから知られている生薬で，消 化管寄生の吸虫, 条虫の駆虫薬として効果がある ことが知られている。

以上の他，未認可であるが厚生省の熱帯病治療 薬の開発研究班員のところに準備されているもの としてクロロキン，キニーネ，メフロキン，プリ マキンなどの抗マラリア薬, 抗卜リパノソーマ薬 としてのスラミン，抗リーシュマニア薬としての 5 価アンチモンであるペントスタムがあり，また 抗包虫すなわち抗エキノコッカス薬としてのアル ベンダゾールなどがある。 もし薬物抵抗性の熱帯 熱マラリアや脳性マラリアあるいはエキノコッカ ス症の症例などに遭遇した時には専門家に相談さ れればこれらの薬物が入手可能である。

\section{5. 輸入感染症に対する対策}

海外旅行予定者から相談があった場合には感染 症に対する配慮を忘れない上らに注意する。まず 流行地に和ける感染予防であるが，各疾患により 異なるものの，人への感染は，(1)水や领食物によ る経口感染，(2)蚊，ダ二などの節足動物の刺咬に よる感染，(3)水や土壤中の幼虫の経皮感染，(4)人 から人への直接感染として空気からの泡沫感染や
接触感染などがあるので，不潔な場所での飲食物 は生で食べないことや虫刺されを防ぐなど，これ らを防御する様に心がける以外にない．末た㷌国 後に体の不調を感じた時には速やかに医師を訪 れ，旅行先で感染可能な疾病に対する検査を依賴 寸ることでする。医師掞よび医療関係者は海外旅 行者が増加している現在，すべての患者に海外旅 行の有無を問診し，疑わしい症状がある場合には 念のため笴生虫症を含む感染症の検査を行うこと が必要である。なお通常の検查室で検査が困難な 場合には大学や研究所など専門の機関に相談, 依 頼することが好むしい。

\section{おわりに}

最近の輸入感染症とくに寄生虫症の現状扣よび その治療についての概略を述べたが，その症例数 は実際にはもっと多いと思われるので，第一線の 先生方が寄生虫性疾患を含めた輸入感染症に目を 向けて戴き，国内での蔓延を早めに防ぐべく心が けて戴ければ幸いだと思う。

な括本講演の内容は厚生省新菜開発研究事業（熱帯病治 潦薬の開発研究]研究費扣上び文部省科学研究費補助金[総 合研究 (A)] (02304036) に上って總められた.

\section{文献}

1) 大交弘士，他：最近 2 年間の输入マラリフ症例の 感染状況の分析。臨床寄生虫研究会誌 2：38， 1991.

2）高田季久：注目されている寄生虫原虫疾患。臨床 娭查 $33 ; 491,1989$.

3）田中寛，他：輸入寄生虫病薬物治療の手引き. 厚生省熱带病治療薬の開発研究班, pp68, 1992.

4）辻 守康, 他：1990 年度の血清反応成續とその治 㙩について教察。臨枺寄生虫研究会誌 $2 ； 15$, 1991.

5）辻 守康：最近の奇生虫症，忩島医学 45：174, 1992. 